\title{
SOCIAL ENTREPRENEURIAL VENTURES IN VIETNAM: AN IDEOGRAPHIC LENS
}

\author{
Yolanda Sarason $^{\mathrm{a}^{*}}$, Kristi Yuthas ${ }^{\mathrm{b}}$, Linh Nguyen ${ }^{\mathrm{c}}$ \\ ${ }^{a}$ The College of Business, Colorado State University, Colorado, USA \\ ${ }^{b}$ School of Business, Portland State University, Portland, USA \\ ${ }^{c}$ The Hanoi - University of Economics \& Business, Vietnam National University, Hanoi, Vietnam \\ ${ }^{*}$ Corresponding author: Email: yolanda.sarason@colostate.edu
}

Article history

Received: December $12^{\text {th }}, 2017$

Received in revised form: January $19^{\text {th }}, 2018 \mid$ Accepted: January $29^{\text {th }}, 2018$

\begin{abstract}
Social entrepreneurial ventures are viewed as valuable tools for generating social and economic wealth and alleviating poverty in emerging economies. While there are many success stories of social ventures, there is a growing focus on the challenges in launching and managing social ventures in these economies. Social ventures in Vietnam face cultural obstacles and advantages that differ greatly from those in the US, where much of the research on social entrepreneurial ventures has focused. One key under-researched difference is culture. We use Hofstede's cultural dimensions theory as an orienting framework for understanding cultural differences between the countries. We use this framework and three case studies of Vietnamese social ventures to develop a series of research propositions about the differences between Vietnam and the US. We suggest implications of these propositions for Vietnamese and US social entrepreneurs and managers and provide guidance for organizations seeking to form culturally sensitive partnerships. Trang's vision for Fargreen's business model was, “... to prove that businesses can do well by doing good, that you can build prosperous and sustainable farming communities, prioritize the environment and still create a successful enterprise. That's why we called it Fargreen - going far by going green". Trang contemplated how much easier it had been to develop Fargreen's business model on paper than to implement it within the complex realities of Vietnam's intricate social ties, evolving political and economic systems, difficult infrastructure, and unique history and culture. These factors amplified the challenges of balancing Fargreen's financial objectives with its social mission (Sarason, Aziz, \& Fifield, 2017).
\end{abstract}

Keywords: Case method; Cultural differences; Hofstede social entrepreneurship; Vietnam.

Article identifier: http://tckh.dlu.edu.vn/index.php/tckhdhdl/article/view/383

Article type: (peer-reviewed) Full-length research article

Copyright (C) 2018 The author(s).

Licensing: This article is licensed under a CC BY-NC-ND 4.0 


\section{INTRODUCTION}

The Fargreen case illustrates the importance of cultural understanding in implementing a social entrepreneurial venture in an emerging economy like Vietnam. Although it is well understood that there are important cultural differences between Vietnam and the United States (Le \& Truong, 2005; Rowley, Truong, \& Warner, 2007), there is little guidance available for social entrepreneurs seeking to achieve social and economic goals with their ventures. Moreover, there is a lack of guidance for companies from these countries seeking to work together. Because social ventures make up an increasingly important sector of business activity in Vietnam, and because the US is a key partner for many Vietnamese social ventures, it is important for entrepreneurs and managers from both countries to understand the implications of these differences.

We begin by giving an overview of social entrepreneurship with an ideographic lens followed by an overview of social venturing in Vietnam. We then an overview of the Hofstede scale that we use as an orienting mechanism to understand cultural differences as they relate to social ventures in Vietnam as compared to social ventures in the US. We next describe three illustrative social ventures in Vietnam and draw upon the experiences of those ventures to develop a set of propositions regarding differences in social ventures in the two countries. We follow each proposition with implications for social entrepreneurs in Vietnam and their US partners.

\section{SOCIAL ENTREPRENEURSHIP RESEARCH - IDEOGRAPHIC LENS}

Increasingly, social entrepreneurial ventures are viewed as valuable tools for generating social and economic wealth and alleviating poverty in emerging economies (Zahra, Rawhouser, Bhawe, Neubaum, \& Hayton, 2008; Seelos, Mair, Battilana, \& Dacin, 2011). Even in markets with serious institutional failures or significant wealth disparities, social ventures have been viewed as conduits toward enhancing social and economic value (Seelos \& Mair, 2007). Nonetheless, there is a growing focus on the challenges of addressing social issues in emerging economies. While the opportunity is clear, there is a critical need to understand how organizations can successfully enter low resource markets, and a call to better understand cultural context in order to unpack how 
social entrepreneurial ventures can be successful (Mair, 2010; Nguyen, Szudlarek, \& Seymour, 2015).

While much existing research focuses on universal, generalizable aspects of social entrepreneurial ventures, we adopt an ideographic lens - viewing phenomena in a historical and cultural context. We apply this lens to compare Vietnam, which has an Eastern culture with a more centrally planned (communist) economy, with the US, which has a Western culture with a more market-driven (capitalist) economy. The ideographic lens can be contrasted with the nomothetic approach used in the majority of research on social enterprises. A nomothetic approach seeks to identify generalizable relationships that can be applied to a broad range of entrepreneurial ventures. It focuses on finding consistencies over time and across populations. This approach typically uses validated consistencies to categorize entrepreneurs and enterprises or to establish characteristics or principles that can be applied to them.

An ideographic approach is associated with research that recognizes the value of exploring differences through the perspective of the subjects experiencing those differences. Studies that use ideographic approaches do not seek to provide broadly generalizable conclusions. Rather, they seek to provide a deep understanding of situated

phenomena that provide insights into real relations and structures (Sarason, Dillard, \& Dean, 2010; Corneliessen \& Clarke, 2010; Suddaby, Bruton, \& Si, 2015; \& Sarason \& Conger, forthcoming).

The ideographic lens used here is based on rich descriptions of social entrepreneurial ventures operating in Vietnam. We combine case analyses, trade publications, and our own experiences to illustrate how these firms exhibit characteristics consistent with the characteristics of the cultures in which they operate.

\section{SOCIAL VENTURES IN VIETNAM}

Prior to Doi Moi in 1986, the state was the only entity responsible for ensuring provision of social services to citizens. The formation and operation of the socio-political organizations such as the Women Union and the Youth Union were always put under the 
leadership of the Communist Party, tied to state management system and these organizations were the only channels for individuals to participate in community activities. During this period, various forms of social organizations operating independently to the government, such as NGOs, were not allowed to operate in Vietnam. Only the state economy and collective economy were recognized as two key economic sectors of the country. In that context, cooperatives were the only suitable form of economic - social organizations established to meet some special needs of its members with community spirits: Cooperation, sharing and for mutual benefit (https://www.britishcouncil.en).

After the inception of the 1986 Doi Moi economic reforms, new doors opened to official development assistance (ODA) funding. With the influx of money, knowledge, and experience, new models and methods appeared to offer support to social development. NGOs and other humanitarian organizations flocked to Vietnam, working on projects to reduce poverty, provide health care and education, and develop access to essentials such as water and electricity. With this change in policy came rapid growth in the development sector that prompted the founding of early-stage social enterprises that operated privately (Cornish, 2017).

Since the inception of the 1986 Doi Moi economic reforms, which enabled development of private and non-profit organizations in Vietnam, business dealings between the US and Vietnam have increased dramatically. There has been work that describes institutional and regulatory differences relevant to trade, including work that describes aspects of Vietnamese culture in for-profit business environments (Rowley et al., 2007). In 2010, external funding for charitable enterprises began to diminish. Nguyen, Luu, Pham, and Tran (2012, p. 22) said:

If we continue to depend on external aid, Vietnam will face the risk of a serious shortage of capital for community development activities in the coming time. Meanwhile, the mobilization of funds from donors and the community in Vietnam is rather limited. A recent study by the Asia Foundation (2011) on charitable contributions in Vietnam shows the great potential contribution from people and 
enterprises, but due to lack of official charitable channels and lack of appropriate policies, most charitable activities are spontaneous, small-scale and limited within small communities. Lack of operational funds places serious pressure on thousands of Vietnamese NGOs and community development projects in the near future.

Beginning in 2014, Vietnam's enterprise regulations have been revised to formally recognize the unique nature of social enterprises. According to the revised Enterprise Law in 2014, social enterprises are expected to hold dual financial and social missions and reinvest a designated portion of profits in pursuit of the mission. In return, these organizations are allowed to receive financial and other donations from both domestic and foreign organizations.

Social entrepreneurship, as sustainable ventures, is considered to be a promising approach for tackling challenging social and environmental issues in Vietnam in recent years. The social entrepreneurship ecosystem is developing rapidly and enjoys the increased participation of various stakeholders including the social enterprises, government, international organizations, impact investors, donors, universities, and media. However, the number of ventures formally registered as social enterprises remain low. It is estimated in a current study conducted by the Centre for Social Innovation and Entrepreneurship, National Economics University that approximately 1,000 ventures are operating as social enterprises, but only 30 registered as social enterprises under the new Enterprise Law (Truong, 2017). The reason there are not many registered social enterprises may be that how to manage a social entrepreneurial venture as for-profit entities is not well understood. However, people are becoming more widely aware of the work of social entrepreneurial ventures and these organizations are more widely accepted as valid forms of business than in the past (Jenkin, 2015). In addition, academic institutions have begun to direct resources toward understanding the social entrepreneurship field. Research centers have been developed, and a broad variety of workshops, conferences and courses have been offered, which help define and add rigor to the understanding of social enterprises in Vietnam (Pham, Nguyen, \& Nguyen, 2016). 
Three primary areas of opportunity described in the Nguyen et al. (2012, p. 60) report are the increasing availability of managerial talent, an entrepreneurial spirit, and the availability of social investment capital from both domestic and foreign markets. The report argues that "to build a reputation with foreign partners, social enterprises must possess professional networking skills, modern management processes, demonstrating accountability, openness transparency." (Nguyen et al., 2012, p. 60). Each of these dimensions requires the ability for both the enterprise and its foreign resource providers to understand and work within the cultural expectations and perspectives of the partner. Successful social entrepreneurial ventures currently operating in Vietnam can be used to illustrate why this is important and how it can be accomplished.

\section{HOFSTED'S MEASURE OF CULTURAL DIFFERENCES}

We use Hofstede's (Hofstede, 1980, 2001; Hofstede \& Hofstede, 2005) wellknown work on culture as a starting point for articulating cultural differences that affect social entrepreneurial ventures. Hofstede (1991, p. 5) defines culture as "the collective programming of the mind that distinguishes the members of one group or category of people from others". Hofstede (1991) uses country as the unit of analysis and focuses on cultural differences between countries. While values and belief systems can vary greatly across individuals within a country, Hofstede's work suggests that the relationships between national and individual culture are strong. Hofstede's ideas have been widely used in management research to describe cultural differences that affect business operations and strategy across geographic regions (Kirkman, Lowe, \& Gibson, 2006; Nguyen, 2017; Khairullah \& Premo, 2015).

The following are the dimensions of national culture as outlined by Hofstede and Hofstede (2005); and Minkov and Hofstede (2011) as well as referenced in Khairullah and Premo (2015). The description of Hofstede's Cultural Dimensions is as follows:

- Individualism/Collectivism: ....Implies a loosely knit social framework in which people are supposed to take care of themselves and of their immediate families only, while collectivism is characterized by a tight social framework 
in which people distinguish between in-groups and out-groups (relatives, organizations, etc.) to look after them, and in exchange for that they feel absolute loyalty to it (Hofstede, 1980);

- $\quad$ Power Distance: ..."The extent to which a society accepts the fact that power is distributed unequally" (Hofstede, 1980, p. 45). In cultures with large power distance, each person has his/her rightful place in society, where there is respect for old age, and status is important to show power. In cultures with small power distance, powerful people try not to show their status and power (de Mooij \& Hofstede, 2002);

- Indulgence/Restraint: This dimension refers to the extent to which people feel that leisure time is more important in their lives, people's happiness level and how much freedom of choice and control people feel they have in their lives (Minkov \& Hofstede, 2011);

- $\quad$ Long-term/short-term orientation: Developed by Hofstede and Bond (1988) means fostering of virtues oriented towards future rewards, and in perseverance and thrift. Short-term stands for encouraging virtues related to the past and present, respect for tradition, preservation of face, and fulfilling social obligations (Hofstede \& Hofstede, 2005);

- Masculinity/Femininity: ..."Masculinity" is concerned with the extent to which the dominant values in a society are "masculine," i.e. assertiveness, the acquisition of money and things, and not caring for others, the quality of life, or people. Femininity on the other hand ... a situation in which the dominant values in society are caring for others and quality of life. Masculinity is an assertive or competitive orientation of thinking and acting (Hofstede, 1980, p. 46);

- Uncertainty-Avoidance: ...Indicates the extent to which individuals in a society feel threatened by uncertain and ambiguous situations and try to 
avoid these situations by providing greater career stability, establishing more formal rules, not tolerating deviant ideas and behaviors, and believing in absolute truths and the attainment of expertise (Hofstede, 1980, p. 46).

Scores on Hofstede's dimensions comparing the US to Vietnam culture are illustrated in Figure 1 (Hofstede Insights, 2017).

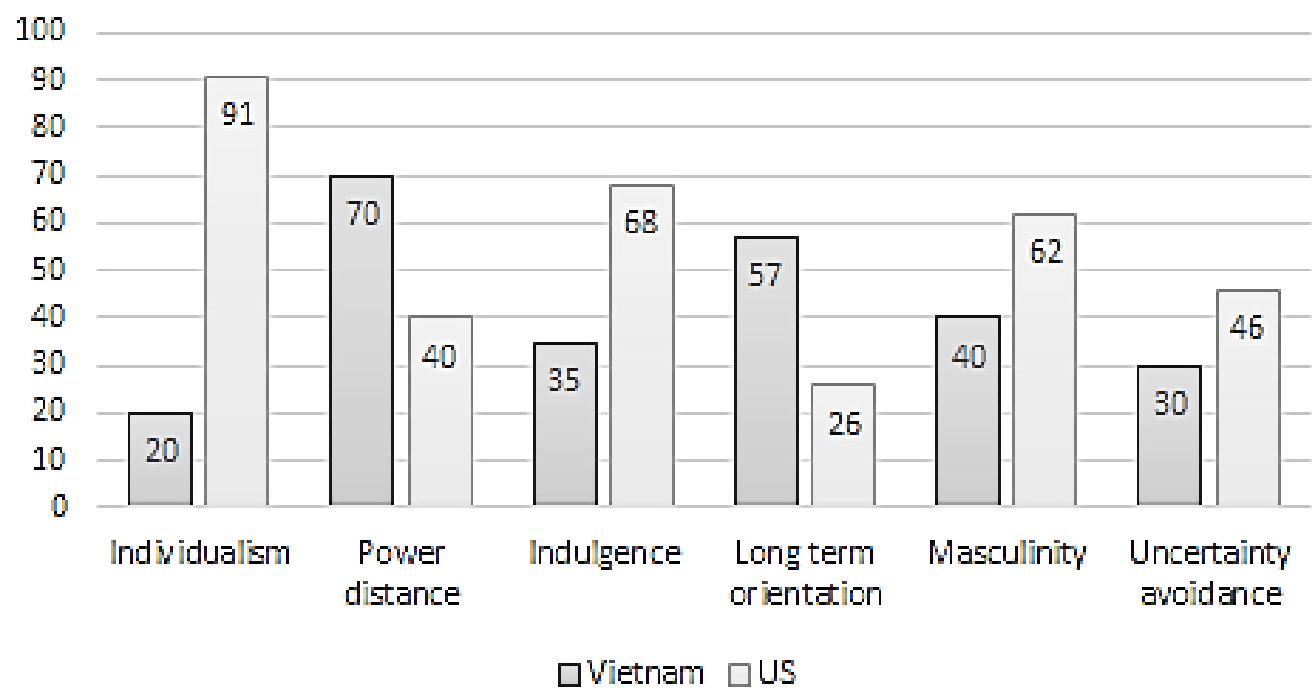

\section{Figure 1. Comparison of cultural dimensions between Vietnam and the US}

This comparison suggests that Vietnam and the US are meaningfully different on all of these six dimensions. Vietnam scores higher on power distance and long-term orientation. The US scores higher on individualism, indulgence, masculinity and uncertainty avoidance. We use Hofstede's cultural dimensions theory as an "orienting framework". While Hofstede's empirical work has received some criticism (Jones \& Alony, 2007), it serves as a useful device for framing the key cultural differences we have identified through our study of academic research and our own experience working with social enterprises in the US and Vietnam. We illustrate the importance of the dimensions with descriptions and examples of how social ventures have been influenced by them. We provide six propositions that explore how social entrepreneurial ventures are perceived, formed, and operated differently in the two countries. For each proposition, we provide implications for the US and Vietnamese partners seeking to work across these cultural divides (see Table 1 for a summary of propositions). 
In these discussions, we draw from Hofstede's work and the work of many others who have summarized the dimensions and discussed them in trade and academic publications. While there are a great many social ventures currently operating in Vietnam, few have reached the size and maturity level that enables them to gain prominence in the press and partnership interest from the US and the broader international community.

\section{THREE VIETNAMESE SOCIAL VENTURES: FARGREEN, VIETNAM HANDICRAFT INITIATIVE, TÒHE}

We have selected three Vietnamese social ventures as subjects to illustrate our propositions. These cases were chosen because they all address cultural issues in Vietnamese social ventures. In addition, they are published teaching cases and the coauthors have worked with two of the ventures. One case focuses a Vietnamese woman starting a for-profit social venture (Fargreen), one focuses on an American working with a social venture (Vietnam handicraft initiative), and one represents a more well-known relatively successful Vietnamese social venture (Tòhe). The cases are the following:

- $\quad$ East meets West: Growing a for-profit venture in Vietnam. (Sarason, Aziz, \& Fifield, 2017);

- Vietnam Handicraft Initiative: Moving toward sustainable operations (Easter \& Dato-on, 2012);

- Tòhe: Stories of women-owned enterprises: Tòhe Vietnam (Seno-Alday \& Nguyen, 2017).

Fargreen, the venture highlighted in the paper's opening quote, has the tagline "Going far by going green." Fargreen was founded in 2015 by current CEO Trang Tran. The venture is targeted at addressing the problem of polluted air from the common practice of burning remnants from rice harvest. She developed a system in which farmers use the leftover rice straw to grow organic mushrooms. The venture is described in the case teaching note as follows (Sarason et al., 2017, p. 1): 
This case focuses on Fargreen, a for-profit social venture started in Vietnam to minimize rice straw burning, a practice that creates significant environmental and health issues. Through the sale of gourmet, branded mushrooms grown in rice straw, the venture generated additional off-cycle income for rice farmers while eliminating toxic greenhouse gas emissions. Fargreen's founder and CEO, Trang Tran, received many awards as a consequence of her focus on using entrepreneurial approaches and developing a robust business model to solve the pressing problem of rice straw burning faced by many Vietnamese citizens.

Trang developed the Fargreen business model while completing an MBA in the United States in a program that focuses on using entrepreneurship to address pressing social issues. After graduating, Trang returned to Vietnam to create her venture. The case begins in the first six months of Fargreen's operations. It addresses common issues faced by new social ventures, such as integrating the venture's social mission into its strategic decisions; potential tradeoffs that can arise while attempting to balance social and financial gain; and addresses the challenges that can occur when using entrepreneurial approaches to start a firm within a country that is just beginning to liberalize its economy.

The Vietnam Handicraft Initiative (VHI) is described in Easter and Dato-on (2012, 2015). VHI is a social venture headquartered in Hue, Vietnam. Founders Lan Nguyen and Trang Tran started the organization to fill gaps they saw in vocational training. They started VHI to provide training and employment for people with mental and physical disabilities. They offered courses in tailoring and sewing and provided housing, food, healthcare, and eventually employment to many of their trainees. As the company matured, it added a handicrafts division and employed professional artisans. The case describes differences and conflicts that arose during the year-long tenure of a US business consultant working with the organization. Easter and Dato-on $(2012$, p. 1) describe the venture as follows:

In January 2010, 25-year-old, MBA graduate Sarah McKenzie boarded an international flight from the United States bound for Vietnam. McKenzie had just 
received her one-year business assignment to work with the Vietnam handicraft initiative (VHI), a vocational training and employment center for people with disabilities, located in Central Vietnam. In the role of business development and marketing advisor, McKenzie was tasked with assisting VHE to increase it's productivity and sustainablility and to strengthen the capacity of the organization through improved business and marketing plans. McKenzie was apprehensive about the report she was expected to provide within the first four weeks of arrival to the international non-government organization (INGO), Volunteer Opportunities Abroad (VOA), which was responsible for her global assignment. In the report, she was to detail her assessment of VHI and provide key recommendations and focused work objectives for the remaining 11 months of her placement. She expected that the many cultural differences would challenge her as she attempted to accurately assess VHI and develop a detailed work plan especially within a few short weeks of her arrival. She would need to hit the ground running and have a game plan constructed within the first day or two after arrival. She was ready to work hard and implement change to improve VHI.

The third organization is Tòne, described in a case by Seno-Alday and Nguyen (2017). Tòhe provides training and opportunities for creating artwork to enrich the lives of children with physical and mental disabilities in Vietnam. It delivers art 'playgrounds' which provide training, art materials, supervision, and space for disadvantaged children to create artwork. Some of this artwork is sold online and in art exhibits, while other artwork is used as inspiration for designs printed on craft products such as clothing and handbags. Tòhe operates in the form of a for-profit company. It invests profit from the organization into socially focused activities. The organization is described in a case by Seno-Alday and Nguyen (2017, pp. 1, 3) as follows:

Tòhe is a social enterprise in Vietnam with a vision of bringing a playful world to disadvantaged children through creative learning playgrounds. The enterprise aims to provide children from disadvantaged backgrounds opportunities to experience and enjoy art and to ultimately to discover their creative potential. The 
journey of Tòhe was a bumpy one in its inception. In a 2016 media interview, Ngân revealed that the founders had been working unpaid for many years and that they had to sell many personal assets in order to maintain the business and continue running their social programs. After 11 years in operation, the business continues to face challenges of profitability and growth.

Despite numerous difficulties, Tòhe generated meaningful impact to the community. Its CEO and co-founder, Ngân Pham, was recognized as one of the most innovative, entrepreneurial and socially-minded women in the world under the age of 40. Ngan was the only Vietnamese in the Forum of Young Global Leaders (YGL) of 2016 recognized by the World Economic Forum (WEF).

\section{PROPOSITIONS FROM HOFSTEDE'S DIMENSIONS ILLUSTRATED WITH CASES}

We now draw upon Hofstede's dimensions to provide six propositions that explore how social entrepreneurial ventures are perceived, formed, and operated differently in the two countries. We draw upon the three cases discussed for illustration of the proposition. For each proposition, we provide implications for the US and Vietnamese partners seeking to work across these cultural divides (see Table 1 for a summary of propositions).

The first two dimensions, individualism and power distance, are illustrated by drawing from the Fargreen case. We find examples of important differences between the US and Vietnam in the relationship between the founding entrepreneur and the employees of the venture and also between the venture and the organizational stakeholders that provide essential resources.

\subsection{Individualism}

Individualism refers to societal interdependence and whether peoples' self-image is defined in terms of "I" or "we". Vietnam has a very collectivist culture where longterm commitment to family, community, and work groups is high. The US is highly individualistic with loose ties to groups. In the US, the founder or initial entrepreneur in 
a business is considered to be responsible for the initial social mission and subsequent successes. When an enterprise does succeed, the entrepreneur is viewed as a hero, particularly when the venture is a social venture. In Vietnam, the founding entrepreneur is also often the face of the venture. However, even though a venture may be associated with one primary person, there will often be a team of key personnel engaged in creating and operating the business that are involved collaboratively in important decisions and relationships. The entrepreneur will have a long-term commitment to teams and groups within the organization and is likely to take their insights and interests into account when making a decision. Thus, we expect:

- P1: Social entrepreneurial ventures in Vietnam will be more strongly associated with the venture, while social entrepreneurial ventures in the US will be more strongly associated with the entrepreneur.

To understand how this dimension affected Fargreen, it is helpful to understand how it affects the way performance is defined and pursued. A lengthy quote from the Fargreen case teaching note summarizes some key differences and illustrates how these differences affect social entrepreneurial ventures:

This reliance on social networks reflected another strong point of contrast between Vietnam and the US: The emphasis on relationships and collectivism over individualism. Whereas Vietnam's long tradition of communal farming had led to a more egalitarian society that prioritized long-term relationships and a grouporiented mentality, the individualism of the US placed greater value on competition and achievement. A new venture based on entrepreneurial principles of innovation, competition, and market disruption could, therefore, have a high potential for conflict when placed in a Vietnamese context, especially within more traditional, collectivist rural communities. Furthermore, the high value placed on self-reliance and independence in US culture differed from the relationship-based culture of Vietnam, which stressed the need to share with and support all members of the group (Sarason et al., 2017, p. 10). 
In organizations, the individualism/collectivism dimension often plays out in the nature of relationships between the entrepreneur and other stakeholders both within and outside of the firm. For example, as a result of the corruption and mistrust in government experienced in Vietnam, potential customers don't necessarily trust labels such as "organically grown" or "quality tested" or " $100 \%$ natural". Thus, the venture needs to form relationships with customers by developing trust over time. Through customer relationships, the organization could tap into broader networks and build its reputation. In Fargreen, similar issues affected the relationships between the venture and the farmers, as well as between Trang and her employees.

...all of Fargreen's projections for scaling and production capacity, as well as impact, had been based on the assumption that Fargreen would be working with individual farmers. After several months at the pilot site, however, Trang learned that rather than one farmer working under each contract, whole families - and sometimes extended families - were working under an individual contract. This meant that most of Fargreen's initial projections were incorrect and would have to be recalculated through different methods (Sarason et al., 2017, p. 10).

This difference has implications for US partners of Vietnamese social ventures. The US partner should not expect to deal only with the social entrepreneur. Buy in from the team may be needed for effective decision making, even if the social venture has a strong entrepreneur. Relationships among members of a social venture and among key stakeholders are characteristically long lasting and strong. Care should be taken when pointing out problems within a social venture so as not to insult the group. In addition, care should be taken so that relationships among all stakeholders are preserved over time.

This difference also has implication for Vietnamese social ventures forming partnership with US organizations. The US entity may be investing their faith or expectations in the social entrepreneur. They may expect changes in operations, strategy, or even mission over time, and will rely on the individual entrepreneur to steer the organization through these changes. US ventures are likely to form a partnership with a venture if they believe strongly in the capabilities of the key individual. As a result, the 
image of that individual is relevant to successful partnerships. Thus, consideration of the entrepreneur's personal branding, and how it might be developed and communicated, may be important when seeking to form relationships with international partners. US partners may prefer to work with one key decision maker instead of a team as this be perceived as less effective decision making.

\subsection{Power distance}

Power distance reflects the extent to which the less powerful members of organizations expect power to reside in the highest levels of the organization and accept that power is distributed unequally. Power also belongs to the government authority in the industry. The hierarchy lies in the fact that government still takes the dominant role in monitoring and intervening in the economy and other aspects of social life (Vuong \& Tran, 2009). Power can also be distributed unequally across business sectors. A social entrepreneurial venture is likely to be at a distinct power disadvantage and assumes lower priority than state-owned enterprises. Such power differences may be more readily accepted by entrepreneurs in Vietnam vs. those in the US who are likely to expect more egalitarian relationships. Thus, we expect that:

- P2: Social ventures in Vietnam are likely to be more hierarchical in decision making authority than social ventures in the US.

The Fargreen case illustrates important differences in power distance norms between the two countries. Because the founder, Trang Tran, had lived and studied entrepreneurship in the US, her expectations for how to run a successful social entrepreneurial venture had a strong US cultural bias. Upon her return to Vietnam, she was surprised by the feeling that elements of Vietnamese life and work now seemed foreign to her. As she began to develop Fargreen, she realized that some of the assumptions she had made while developing her business model had been based more on political, economic, and cultural realities of the US than those of Vietnam; She would have to adjust to working in a different type of business environment if Fargreen was to succeed (Sarason et al., 2017, p. 8). 
Power distance was described in the Fargreen case as follows: The Vietnamese culture is more accepting of the lack of equality in opportunity than the US culture. A higher level of comfort with hierarchy (Hofstede's Power Distance measure) results in the expectation that decisions are made at the top with little expectation of initiative and innovation at the lower levels of the organization. Innovation at all levels within the firm, and the ability to pivot and adapt to changing circumstances are considered to be essential in entrepreneurial ventures and could be particularly valuable in the difficult and rapidly changing circumstances of ventures addressing social problems. Trang had a desire for her employees to take initiative in improving processes and practices, and thereby accept more power in the decision-making hierarchy. But the employees were enculturated to respect hierarchy, and they looked to Trang for direction in these decisions.

This heightened respect for authority also has an important impact on who feels empowered to push for changes. According to the case, respect for power distance at Fargreen "also constrains bottom-up information flow, regarding bad news. There is also a reluctance to challenge authority" (Sarason et al., 2017, p. 4). Lack of strong mechanisms to convey information about problems and opportunities, to suggest changes, and to question the status quo might constrain a social entrepreneurial venture in its ability to effectively and rapidly respond to market and stakeholder demands.

This difference also has implication for US partners of Vietnamese social ventures. The US partner should identify people who hold status and decision-making power within the organization and work through those people to obtain approvals, develop partnerships, or formulate decisions. Attempting to work directly with lower status individuals might trigger longer time or ineffective transactions because in the end all the important decisions are still made or approved by authority figures of the enterprise. This might seem inconsistent with the collectivism described above, and US partners might expect decisions to be made by the entrepreneur or supervisor in charge. However, there may be a norm of forming consensus before important decisions are made. Pushing authority down to lower levels in an organization might also be 
problematic with individuals who are not comfortable or accustomed to taking responsibility.

The difference also has implications for Vietnamese social ventures forming partnerships with the US. organizations. It should be noted that many US partners are not accustomed to working through formal hierarchies, especially entrepreneurial ventures. Decision makers in parallel roles may expect to communicate directly and will likely be accepting of such communication. Relationships among employees are more egalitarian and informal, and individuals are likely to call people higher in the organization by their first names. Individuals from the US may also be comfortable questioning or contradicting their bosses, and disrespect should not be assumed.

The next two dimensions, indulgence, and long-term orientation are discussed drawing upon the VHI case (Easter \& Dato-on, 2012). The US and Vietnamese social ventures tend to have differing perspectives regarding the prioritization of performance goals and the timeframe within which they achieve these goals.

\subsection{Indulgence}

Indulgence reflects the degree to which a society approves of free gratification of desires. In the US, individuals are socialized to follow their impulses and desires, and pursuit of personal gains as well as leisure time are acceptable. Restrained societies, such as that in Vietnam, value control over impulses and desires and individuals may feel more restrained in pursuit of personal rather than collective gains. Social ventures in Vietnam may be less oriented toward personal benefits for owners and managers or financial benefits to the firm and more oriented toward benefits to society than in the US. Thus,

- P3: A dual focus on societal and financial outcomes will be more accepted for social entrepreneurial ventures in Vietnam than in the US.

The case of VHI illustrates cultural differences among the US and Vietnamese social ventures in terms of organizational focus. An American consultant to VHI worked to focus immediately on improving the organization's financial performance. The 
consultant could see that the organization's current business model was not successful, and that although the organization's handicrafts were built in a manner that focused on social improvement, the products themselves had difficulty competing on quality and price with those of for-profit competitors. She believed the first objective was to deal with these deficits by improving efficiency and quality in production.

The director of the social entrepreneurial venture continued focusing primarily on societal outcomes. Rather than working to improve financial performance through sales, she sought to enhance fundraising through grant opportunities, which would enable continued training and employment of disadvantaged workers and thereby enhance social outcomes. The difference in whether the social mission or financial sustainability of the organization is more important can be seen to be related to Hofstede's indulgence dimension. The Vietnamese manager continued to prioritize the needs of clients even as the organization's own survival was threatened. Further, in order to implement process changes associated with financial performance, the employees who were the beneficiaries of the social mission would have to be included and be willing to accept the new practices. The financially-oriented suggestions made by prior US managers in roles similar to that occupied by McKenzie had been unsuccessful.

Public social ventures in the U.S are pressured to return a financial return to their shareholders as well as follow their social mission. It is debated whether this is possible or whether these public firms are 'selling out' in focusing on financial profits (Sarason \& Dean, 2017). Similarly, Yuthas and Thomas (2016) have likewise argued that western funders and impact investors similarly prioritize and monitor financial performance and can neglect social performance of the venture.

The implication for U. S. organizations working with Vietnamese partners is that there is benefit from understanding that Vietnamese partners are likely to prioritize social performance over financial performance. Attention and resources may be directed toward programs that benefit constituents first and the venture second. The difference also has implications for Vietnamese social ventures forming partnerships with US organizations. It should be noted that US partners might desire and be expected to obtain benefits for 
themselves and their organizations through their partnerships. They may assume and expect that Vietnamese partners have the same degree of self-interest. Survival of the firm and ongoing employment of key personnel may take top priority and social goals may be elevated only after financial sustainability is achieved.

\subsection{Long-term orientation}

Long-term orientation describes how societies relate to time. Vietnam's longerterm focus suggests a perspective that truth depends on situation, context and time, and perseverance is honored. The short-term focus in the US may influence prioritization of short-term performance and quick results, and relationships with stakeholders may be more transactional and goal oriented as a result. Thus,

- P4: Social entrepreneurial ventures in Vietnam will have a longer-term horizon for stakeholder relationships than in the US.

The case of VHI illustrates the importance of cultural differences in long-term orientation across the two countries. In this case, an American international marketing manager working through the organization Volunteer Opportunities Abroad takes a oneyear assignment to help VHI with capacity building, productivity, and sustainability (Easter \& Dato-on, 2012). McKenzie, the volunteer described in the case, had difficulties working with the non-profit both because she and the social entrepreneur had differing goals for what was to be accomplished while she was in Vietnam. The volunteer assumed she would be working on capacity building and the social entrepreneur assumed the volunteer would be writing grants. They also differed on their relationship to each other over time. As an outsider, McKenzie tried to push her ideas quickly forward using her own logic and job expectations but was unable to make much progress.

For Vietnamese social ventures like VHI, the importance of developing and sustaining relationships with stakeholders over long periods of time must be held in high priority. These relationships and the related social capital serve as assets that can help both organizations accomplish their objectives (Easter \& Dato-on, 2015). At VHI, the consultant failed to take the time to establish these relationships, and this contributed to 
her difficulties in accomplishing her goals. In addition, employees at VHI knew she would only be with the organization for one year, so they may not have invested heavily in what they viewed as a short-term stakeholder relationship.

This illustrates the implication for US partners of Vietnamese social ventures. VHI relationships with key stakeholders are representative of the manner in which Vietnamese social ventures conduct business with their partners. VHI had strong relationships with governmental partners, customers, and even businesses in the local area. Partners invest heavily over time in forming these relationships, and once formed, are viewed as long-term partnerships, and long-term contracts are common. These partnerships are characterized by a great deal of reciprocity and information exchange that results from the deep, almost family-like ties formed between business partners.

Social ventures in the US, by contrast, may have more transactional relationships with partners. For example, funding relationships with grant-making organizations or impact investors can be short-term in nature, requiring social entrepreneurial ventures to continually seek out and form new partnerships. Similarly, contracts with customers, suppliers, and other trading partners may be influenced more heavily by performance goals and the competitive landscape and may, therefore, be shorter term in nature as well.

The last two dimensions, masculinity and uncertainty avoidance can be related to the manner in which social ventures exercise control and accountability through management control systems. We illustrate these dimensions by drawing upon the case of Tòhe.

\subsection{Masculinity}

Masculinity associates a high score with a focus on competition, achievement, and success, while a low score is associated with a focus on caring for others and quality of life. Social entrepreneurs in the US are more likely to organize as for-profit ventures and they focus on financial and social goals (Defourny \& Nyssens, 2010). Vietnamese social ventures are more likely to be organized as not for profits and therefore be less focused on financial performance. In the US, social ventures may be more sensitive to the 
competitive landscape and view success in terms of both achieving social and financial goals and outperforming competitors. They may be more likely to compare their own performance and the performance of their competitors on quantitative terms, and as a result, may be more likely to invest in performance monitoring systems. In Vietnam, direct comparisons with competitors are less common and less acceptable. Using social performance from charitable activities to promote the organization, while encouraged and accepted in the US is frowned upon in Vietnam and considered to be an abuse of funds making it less valuable to track social performance (Nguyen et al., 2012, p. 33). Thus:

- P5: Social entrepreneurial ventures in Vietnam will place less emphasis on measuring and communicating impact performance than will US social ventures.

Tòhe was among very few social enterprises in Vietnam successful in mobilizing local and international donors and investors. For example, Tòhe received funding from the Centre for Social Initiatives Promotion (CSIP), the British Council in Vietnam and the German development cooperation agency (GIZ) to assist it to launch products to the market and enhance its capacity. In addition, they received funding from Thriive US and LGT Venture Philanthropy to improve its business performance and scale its impact on the community. Over its years of existence, Tòhe has faced financial challenges and has restructured its operations and funding streams to ensure its ongoing success.

While regular entrepreneurs concentrate on maximizing profits, Tòhe's founders care a lot about helping their benefactors. Efforts to do this include an innovative working environment filled with love and happiness as well as opportunities for children to learn, enjoy and play. Pham (2017) stated:

We are not in a rush for profits ahead of the values to which we are committed. Although the road ahead is long we are proud of what we've done and generations of staff, customers and clients have over the years felt that spirit and chosen to stay with us (Pham, personal communication, December $\left.13^{\text {th }}, 2017\right)$. 
Tòhe is well-known in the not-for-profit sector for its meaningful impact to the community. By 2016, the enterprise has created more than 150 art playgrounds and engaged over one thousand children with disabilities in over 20 primary schools and social support centers (Central Institute of Economic Management, British Council, \& National Economics University, 2016). From experience working with many stakeholders, Pham (2017) saw that investors, intermediaries and other resource providers tend to have a strong emphasis on measuring and reporting impact performance. However, Tòhe appears not to focus much on measuring and communicating impact performance formally (Pham, personal communication, December $13^{\text {th }}, 2017$ ).

The implication for Vietnamese social ventures is to recognize that U.S partners may expect to hear about achievements and successes of the organization and of key individuals. Moreover, they may assume that these successes are lacking if they are not reported. Vietnamese managers may need to be explicit about their measurement of financial and social impact when dealing with US partners.

The implication for US partners is it is important to recognize that Vietnamese partners' accomplishments may be understated and under promoted because Vietnamese do not value self-promotion about the successes of their organizations. US partners may need to engage in conversations and other forms of inquiry to uncover a complete picture of the social and financial performance of the firm.

\subsection{Uncertainty avoidance}

Uncertainty avoidance references how a society deals with ambiguity and an unknowable future. Vietnam's history of continuous wars and unpredictable changes in society has shaped the country to be one of the lowest on uncertainty avoidance dimensions and enabled the Vietnamese to adjust well to new circumstances and handle uncertainty and ambiguity in life (Hopkins, 2009). Vietnam's low score suggests a more relaxed attitude toward dealing with uncertainty. In the US there is evidence that entrepreneur manages risk by what is becoming understood to be 'affordable risk' from an effectuation perspective (Sarasvathy, 2001). With the additional challenges of dual 
missions, social ventures in both cultures arguably subject to greater uncertainty than other ventures. Because of the relatively higher ability to accept risk in Vietnamese culture, Vietnamese social entrepreneurial ventures may be more accepting of change and variances from expectations. They may be more willing to pivot and reposition their efforts and focus in light of changes in their environments or organizations. Thus,

- P6: Social entrepreneurial ventures in Vietnam are more likely to have weaker management control systems than in the US social ventures.

Tòhe was established in 2006 because the social entrepreneurs believed they could commercialize their ideas of bringing innovative products produced by disadvantaged children to life. Initially, these founders expended significant financial resources into the business. By 2012, the number of followers on Tòhe's fan page increased rapidly and they opened six retail stores in the biggest cities of Vietnam. However, sales did not meet projections and they began to run out of money. By 2015, the founders had developed stronger management control systems and reached break-even and were profitable in 2016.

In spite of their high profile in the social enterprise sector, Tòhe does not appear to have a strong management control system by US standards. The founders of Tòhe had their strategies and plans, but they were mainly 'in their heads'. Ngan revealed that the strategies and plans were not very well documented. They have made several changes throughout their years of operations as their needs and direction changed. One of their investors, LGT Venture Philanthropy, says that $95 \%$ of Vietnamese social entrepreneurial ventures are difficult for investors to work with because of "the uncertain standards of the financial statements and operation plans", and the lack of ability to rapidly scale (Nguyen, 2015). 
Table 1. Summary of Hofstede's scores, propositions, predictions, and implications

\begin{tabular}{|c|c|c|}
\hline & U.S & Vietnam \\
\hline Individualism & Score $91 / 100$ & Score $20 / 100$ \\
\hline Proposition & \multicolumn{2}{|c|}{$\begin{array}{l}\text { P1: Social entrepreneurial ventures in Vietnam will be more strongly associated } \\
\text { with the venture, while social entrepreneurial ventures in the US will be more } \\
\text { strongly associated with the entrepreneur. }\end{array}$} \\
\hline Implication & $\begin{array}{l}\text { Team buy-in important; expect and } \\
\text { protect long-term relationships. }\end{array}$ & $\begin{array}{l}\text { US may rely more on entrepreneur } \\
\text { than team; Entrepreneur's brand is } \\
\text { important }\end{array}$ \\
\hline $\begin{array}{l}\text { Power } \\
\text { distance }\end{array}$ & Score $40 / 100$ & Score 70/100 \\
\hline Proposition & \multicolumn{2}{|c|}{$\begin{array}{l}\text { P2: Social Ventures in Vietnam are likely to be more hierarchical in decision } \\
\text { making authority than social ventures in the US. }\end{array}$} \\
\hline Implication & $\begin{array}{l}\text { Identify and work through people with } \\
\text { power and authority. Take care when } \\
\text { contradicting leaders. }\end{array}$ & $\begin{array}{l}\text { US may expect direct, parallel } \\
\text { communication. Informality and } \\
\text { questioning superiors are the norm. }\end{array}$ \\
\hline Indulgence & Score $68 / 100$ & Score $35 / 100$ \\
\hline Proposition & \multicolumn{2}{|c|}{$\begin{array}{l}\text { P3: A dual focus on societal and financial outcomes will be more accepted for } \\
\text { social entrepreneurial ventures in Vietnam than in the US. }\end{array}$} \\
\hline Implication & $\begin{array}{l}\text { Expect social beneficiaries to be } \\
\text { prioritized when allocating attention and } \\
\text { resources. }\end{array}$ & $\begin{array}{l}\text { US may accept and expect self- } \\
\text { interested, financially oriented } \\
\text { priorities. }\end{array}$ \\
\hline $\begin{array}{l}\text { Long term } \\
\text { orientation }\end{array}$ & Score $26 / 100$ & Score $57 / 100$ \\
\hline Proposition & \multicolumn{2}{|c|}{$\begin{array}{l}\text { P4: Social Entrepreneurial ventures in Vietnam will have a longer-term horizon } \\
\text { for stakeholder relationships than in the US. }\end{array}$} \\
\hline Implication & $\begin{array}{l}\text { Deep, family-like partnerships with } \\
\text { stakeholders are common. }\end{array}$ & $\begin{array}{l}\text { US relationships with partners are } \\
\text { often short-term and transactional. }\end{array}$ \\
\hline Masculinity & Score $62 / 100$ & Score $40 / 100$ \\
\hline Proposition & \multicolumn{2}{|c|}{$\begin{array}{l}\text { P5: Social entrepreneurial ventures in Vietnam will place less emphasis on } \\
\text { measuring and communicating impact performance than will US social ventures. }\end{array}$} \\
\hline Implication & $\begin{array}{l}\text { Self-promotion is not valued and } \\
\text { accomplishments may be understated. }\end{array}$ & $\begin{array}{l}\text { Convey information and evidence } \\
\text { about achievements and successes. }\end{array}$ \\
\hline $\begin{array}{l}\text { Uncertainty } \\
\text { avoidance }\end{array}$ & Score $46 / 100$ & Score $30 / 100$ \\
\hline Proposition & \multicolumn{2}{|c|}{$\begin{array}{l}\text { P6: Social entrepreneurial ventures in Vietnam are more likely to have weaker } \\
\text { management control systems than in the US social ventures. }\end{array}$} \\
\hline Implication & $\begin{array}{l}\text { Environment is seen as changing and } \\
\text { unpredictable; formal control systems } \\
\text { aren't the norm. }\end{array}$ & $\begin{array}{l}\text { US may require clearly-defined } \\
\text { policies, data collection, and } \\
\text { reporting processes. }\end{array}$ \\
\hline
\end{tabular}

Although strong management control is the norm in many US firms, rigid systems can stifle innovation and the ability to respond to dynamic conditions. Because the 
economy in Vietnam and the competitors and partners in Tòhe's sphere of interaction change rapidly, the ability to thrive in uncertain conditions may be a distinct advantage for social entrepreneurial ventures in Vietnam. The implication for the US firms is that they should recognize that Vietnamese social ventures assume that their environment is assumed to be unpredictable and subject to continuous change. They may not have formal management control systems and may not have the kinds of data and reports that would be familiar to US organizations.

For Vietnamese partners, the implication is that they may need to understand that US partners may expect and require more clearly defined policies, data collection, and reporting processes before they are comfortable making financial and trading commitments with the organization. Uncertainty and risk translate to volatility and unpredictability in both financial and social returns and therefore US firms facing these circumstances may expect higher returns. Table 1 summarizes our propositions and implications by cultural dimension.

Social entrepreneurial ventures have the potential for addressing critical social problems such as the growing disparity of incomes and increasing degradation of the environment. While social entrepreneurial ventures have been viewed as essential economic engines for development in emerging economies, there is insufficient research on important dimensions of these organizations and how they differ from those in heavilyresearched developed countries. A better understanding of how culture influences the orientation, organization, and operation of these enterprises can inform those who wish to implement, regulate, or work effectively with them. Viewing these ventures through a country-specific ideographic lens provides a conceptual foundation, and the set of propositions suggested here provide an important starting point for understanding social entrepreneurial success.

\section{CONCLUSION}

Our goal has been to better understand how culture impacts the management of Vietnamese social ventures and how US social ventures can better partner with them. We 
drew upon Hofstede's cultural dimensions to better unpack national culture in contrast to American culture. We developed propositions for each dimension and illustrated the propositions with examples from published cases. Here we present a summary of implications for American and Vietnamese social ventures working together. These implications are particularly germane to social ventures as the impact goals go beyond financial sustainability.

Because Americans are more individualistic and Vietnamese are more collectivist, the relationships may be facilitated if Americans recognize that it is important to gain acceptance from the entire social venture team and that long-term relationships are to be expected and respected. It would be helpful if Vietnamese managers recognize that it is common for Americans to attribute successes to individuals rather than the organization as a whole. Since there is a greater power distance in Vietnamese social ventures, it may be more effective for Americans to work with individuals with designated authority. Moreover, it would be helpful if Vietnamese managers recognize that their American partners may expect direct, parallel communication and that informality is common as is questioning authority. Since Americans are more likely to be indulgent, it might be helpful for both parties to recognize that it is common for Americans to be more selfinterest driven and for Vietnamese to be more focused on the common good. Because of the differences in time orientation, would be helpful for both parties to focus on both short-term consequences as well as the long-term consequences of all partnerships. Because the Vietnamese culture is a more feminine culture, it would be helpful for both parties to recognize that self-promotion is not common and accomplishments may be understated in Vietnam. Since Americans are less comfortable with uncertainty, it would be helpful for both parties to recognize that formal control systems are not the norm in Vietnamese culture and accommodations from both sides would foster a more meaningful relationship.

As we move toward a more global marketplace, partnerships between Vietnamese ventures and US ventures will be more common. With social ventures, both partners want to achieve the social missions they are committed to achieve. Given the potential of social 
ventures to address social issues such as poverty, climate change, and pollution, it is imperative that both sides understand how to work together to have an even greater impact. Understanding cultural differences with an ideographic lens is an essential step toward these goals.

\section{REFERENCES}

Central Institute of Economic Management, British Council, \& National Economics University. (2016). Tòhe: A happy business model for disadvantaged children. In N. D. Cung (Eds.), Vietnam Social Enterprise Casebook (pp. 72-78). Hanoi, Vietnam: CEIM.

Cornelissen, J. P., \& Clarke, J. S. (2010). Imagining and rationalizing opportunities: Inductive reasoning and the creation and justification of new ventures. The Academy of Management Review, 35(4), 539-557.

Cornish, P. (2017). Social enterprise in Vietnam. Retrieved from https://www. asialifemagazine.com/vietnam/social-enterprise-vietnam/

Defourny, J., \& Nyssens, M. (2010). Conceptions of social enterprise and social entrepreneurship in Europe and the United States: Convergences and divergences. Journal of Social Entrepreneurship, 1(1), 32-53.

de Mooij, M., \& Hofstede, G. (2002). Convergence and divergence in consumer behavior: Implications for international retailing. Journal of Retailing, 78(1), 61-69.

Easter, S., \& Dato-on, M. C. (2012). Vietnam Handicraft Initiative: Moving toward sustainable operations. Ontario, Canada: The University of Western Ontario.

Easter, S., \& Dato-on, M. C. (2015). Bridging ties across contexts to scale social value: The case of a Vietnamese social enterprise. Journal of Social Entrepreneurship, 6(3), 320-351.

Hofstede. G. (1980). Culture's consequences: International differences in work-related values. California, USA: Sage Publications.

Hofstede. G. (1984). Culture's consequences: International differences in work-related values. California, USA: Sage Publications.

Hofstede, G., \& Bond, M. (1988). The Confucius connection: From cultural roots to economic growth. Organizational Dynamics, 16(4), 4-21.

Hofstede. G. (1991). Cultures and organizations: Software of the mind. Maidenhead, UK: McGraw-Hill Press.

Hofstede. G. (2001). Culture's consequences: Comparing values, behaviors, institutions, and organizations across nations ( $2^{\text {nd }}$ ed.). California, USA: Sage Publications.

Hofstede, \& Hofstede. (2005). Cultures and organizations: Software of the mind. New 
York, USA: The McGraw-Hill Companies, Inc.

Hofstede, G., \& Minkov, M. (2010). Long-versus short-term orientation: New perspectives. Asia Pacific Business Review, 16(4), 493-504.

Hofstede Insights. (2017). Cultural comparison. Retrieved from https://www.hofstedeinsights.com/country-comparison/the-usa,vietnam/

Hopkins. B. (2009). Cultural differences and improving performance: How values and beliefs influence organizational performance. Farnham, England: Gower Press.

Jenkin. M. (2015). It's not charity: The rise of social enterprise in Vietnam. Retrieved from https://www.theguardian.com/sustainable-business/2015/mar/31/its-notcharity-the-rise-of-social-enterprise-in-vietnam.

Jones, M. L., \& Alony, I. (2007). The cultural impact of information systems - Through the eyes of Hofstede - A critical journey. Issues in Informing Science \& Information Technology, 4, 407-419.

Khairullah, D. H., \& Premo, K. M. (2015). Environment and management implications: A study of Vietnam. Business Studies Journal, 7(1), 1-13.

Kirkman, B. K., Lowe K., \& Gibson, C. (2006). A quarter-century of "culture's consequences": A review of empirical research incorporating Hofstede's cultural values framework. Journal of International Business Studies, 37(3), 285-320.

Le, C. T., \& Truong, Q. (2005). Antecedents and consequences of dimensions of human resource management practices in Vietnam. The International Journal of Human Resource Management, 16(10), 1830-1846.

Mair, J. (2010). Social entrepreneurship: Taking stock and looking ahead. In A. Fayolle and H. Matlay (Ed.), Handbook of Research on Social Entrepreneurship. Cheltenham, UK: Edward Elgar Publishing.

Minkov, M., \& Hofstede, G. (2011). The evolution of Hofstede's doctrine. Cross Cultural Management: An International Journal, 18(1), 10-20.

Nguyen, D. C., Luu, M. D., Pham, K. O., \& Tran, T. H. G. (2012). Social enterprise in Vietnam: Concept, context, and policies. Hanoi, Vietnam: Central Institute of Economic Management.

Nguyen, T. B. N. (2015). LGT Venture Philanthropy invests in Vietnam's Tohe, Ecolink. Retrieved from https://www.dealstreetasia.com/stories/lgt-venture-philanthropyinvests-in-vietnams-tohe-ecolink-5427/

Nguyen, L., Szkudlarek, B., \& Seymour, R. G. (2015). Social impact measurement in social enterprises: An interdependence perspective. Canadian Journal of Administrative Sciences, 32(4), 224-237.

Nguyen, H. T. (2017). The effects of performance appraisal on employee retention: A comparison of Finnish and Vietnamese enterprises. Dalat University Journal of Science-Economics and Management, 7(1), 23-54.

Pham, T. N. (2017). Personal interview. 
Pham, T. V., Nguyen, H. T. H., \& Nguyen, L. (2016). Social enterprises in Vietnam (Working Paper No. 31). Retrieved from https://www.iap-socent.be/sites/default/ files/Vietnam\%20-\%20Pham\%20et\%20al.pdf

Rowley, C., Truong, Q. D., \& Warner, M. (2007). To what extent can management practices be transferred between countries? The case of human resource management in Vietnam. Journal of World Business, 42(1), 113-127.

Sarason, Y., Aziz, A., \& Fifield, E. (2017). East meets West: Growing a for-profit venture in Vietnam. Retrieved from: https://wdi-publishing.com/product/east-meets-westgrowing-profit-social-venture-vietnam/

Sarason, Y., \& Conger, M. (Forthcoming). Ontologies and epistemologies in 'knowing' the nexus in entrepreneurship: Burning rice hay and tracking elephants. International Journal of Entrepreneurship and Small Business. Retrieved from: http://www.inderscience.com/jhome.php?jcode=ijesb

Sarason, Y., \& Dean, T. (2017). Structuring for social and environmental impact: From "selling out" to "selling in" in the sale of natural and organic product ventures. Paper presented at The Academy of Management Atlanta, USA.

Sarason, Y., Dillard, J., \& Dean, T. (2010). How can we know the dancer from the dance? Reply to "Entrepreneurship as the structuration of individual and opportunity: A response using a critical realist perspective". Journal of Business Venturing, 25(2), 238-243.

Sarasvathy, S. (2001). Causation and effectuation: Toward a theoretical shift from economic inevitability to entrepreneurial contingency. The Academy of Management Review, 26(2), 243-263.

Seno, A. S., \& Nguyen, L. (2017). Stories of women-owned enterprises: Tòhe Vietnam. Sydney, Australia: The University of Sydney.

Seelos, C., \& Mair, J. (2007). Profitable business models and market creation in the context of deep poverty: A strategic view. Academy of Management Perspectives, 21(4), 49-63.

Seelos, C., Mair, J., Battilana, J., \& Dacin, T. (2011). The embeddedness of social entrepreneurship: Understanding variation across local communities. In C. Marquis, M. Lounsbury, \& R. Greenwood (Eds.), Research in the Sociology of Organizations, Communities and Organizations (pp. 333-363). Bingley, UK: Emerald Press.

Sower, V. E., \& Sower, J. C. (2005). Moderator variables in cultural values and business ethics research: Important to external validity. Southwest Business and Economic Journal, 13, 1-18.

Suddaby, R., Bruton, G. D., \& Si, S. X. (2015). Entrepreneurship through a qualitative lens: Insights on the construction and/or discovery of entrepreneurial opportunity. Journal of Business Venturing, 30(1), 1-10.

Truong, M. (2008). Perception of corporate social responsibility in Vietnam: A study of 
executive management students. International Vision, (12), 107-118.

Truong, M. (2017). Social enterprises in Vietnam: Strategies, models and policy implications. Paper presented at The Annual International Conference on Social Entrepreneurship (ICSE 2017), Vietnam.

Truong, Q. D., \& Metzger, C. (2007). Quality of business graduates in Vietnamese institutions: Multiple perspectives. Journal of Management Development, 26(7), 629-643.

Truong, Q., Swierczek, F. W., \& Chi, D. T. K. (1998). Effective leadership in joint ventures in Vietnam: A cross-cultural perspective. Journal of Organizational Change Management, 11(4), 357-372.

Vuong, Q. H., \& Tran, T. D. (2009). The cultural dimensions of the Vietnamese private entrepreneurship. The IUP Journal of Entrepreneurship and Development, 6(3\& 4), 54-78.

Yuthas, K., \& Thomas, E. A. (2016). Performance over promises. In E. A. Thomas (Eds.), Broken Pumps and Promises: Incentivizing Impact in Environmental Health. Gewerbestrasse, Switzerland: Springer International Publishing.

Zahra, S. A., Rawhouser, H. N., Bhawe, N., Neubaum, D. O., \& Hayton, J. C. (2008). Globalization of social entrepreneurship opportunities. Strategic Entrepreneurship Journal, 2(2), 117-131. 